"Fungi of the Neighbourhood of Greenwich," which was printed in the fifth volume of the Phytologist. In 1857 a committee of that Club was appointed to draw up a report on the flora of the district; Mr. Currey was chosen its chairman, and drafted the report, which enumerated 395 fungi. In that year he contributed a paper to the Royal Society, which was printed in the Proceedings, On the Occurrence of Amorphous Starch in a Tuberaceous Fungus, a point of much interest, as starch is rarely found in fungi. $\mathrm{He}$ was elected Fellow of the Linnean Society in 1856 , and in 1858 Fellow of the Royal Society also; in 1860 he was appointed secretary of the former society in succession to Mr. J. J. Bennett, a post which he held until 1880 , when he relinquished that office and acceded to the less arduous duties of treasurer, retaining that appointment until his death. In 1862 the Ray Society issued a translation, with considerable additions, from Hofmeister, entitled "On the Germination, Development, and Fructification of the Higher Cryptogamia," a task which Mr. Currey undertook in 1859; the following year he edited a second edition of Dr. Badham's "Esculent Funguses of England," in which he made as few alterations as possible. Several papers on mycological subjects appear in the Transactions of the Linnean Society, which will be found in the "Catalogue of Scientific Papers," under his name, his last contribution being, "On a Collection of Fungi made by Mr. Sulpiz Kurz," in 1876.

By his death the Linnean Society has lost an experienced officer, and its members a valued friend whose place it will be hard to fill.

\section{THE AMERICAN ASSOCIATION}

THE thirtieth meeting of the American Association for the Advancement of Science commenced at Cincinnati on August I6. Always a hot place in summer, the temperature at Cincinnati during the past two months has been at intervals unusually high, running above $100^{\circ}$ for several days together. This and the fear of its recurrence no doubt induced many to stay away who would otherwise have been present. However, a goodly number - over 400-of new members were enrolled, and many papers of interest were read. Some of the visitors from the Eastern States were amazed to find that Cincinnati was not a little backwoods town, but a city deserving in many ways the title she claims, "The Queen City of the West." The ignorance of many of the inhabitants of the Eastern States in regard to the West is only equalled by the ignorance of Europeans in regard to America generally.

The citizens of Cincinnati exerted themselves to welcome their guests, and did it well. Their bodily wants were amply supplied, and this, to those coming from a distance and being strangers, was a matter of no small moment. Visitors knowri or bearing introductions were in very many cases entertained privately, and a free lunch was provided by subscription for all members daily from I to 2.30 p.m. The Western Union Telegraph Compariy, whose wires extend over almost the whole Union, gave the members the use of their lines for communication with their families, free of charge, at whatever distance they might be situated. Con nection was made by telephone between the hall of meeting and the Central Telegraph Office, and between the various rooms in the building, so that it was possible to send a message without leaving the building-to ask, for example, what paper was being read in any other section. The City and Suburban Telegraph and Telephone Companies also extended the same privileges to members of the Association. The various Express Companies offered to convey light parcels containing specimens for them, free of charge, between their homes and the place of meeting, and heavy ones at low rates. Of course there was a post-office and a parcels office in the hall, with convenience and materials for writing. There was however a little deficiency in finger placards to direct strangers over the great building in which the meetings were held - the new music hall.

Besides the above, an excursion was arranged for Saturday afternoon to the Zoological Garden, one of the best in the country, and capable, if well supported, of becoming the best. Free transportation through the streets by the horse cars was provided, and a sumptuous repast prepared for the visitors before leaving. In the same way the Anthropological Section and others were taken out to Madisonville, about ten miles from the city, on Monday to see a prehistoric cemetery recently discovered, from which several hundred skeletons, uncounted arrowpoints, animal bones, horns, and teeth, and pieces of pottery have been exhumed during the past two years. The train stopped at the place to set them down, and again on its return to take them up. After the adjournment of the meeting an excursion was arranged to the Mammoth Cave, about 150 miles distant, and another to Chattanooga, about 300 miles over the new Southern Railway, both free so far as the travelling was concerned.

It will be evident that Cincinnati did her best to entertain her scientific visitors, and the latter carried away pleasant and lasting impressions of the city where the fifth and the thirtieth meetings of the Association were held, the latter having been one of the most successful in its history.

E. W. Claypole

\section{Another correspondent writes :-}

The Cincinnati meeting proved to be one of the best ever held by the Association. In attendance of members it was much surpassed by the Boston meeting last year, which reached the phenomenal number of 997 ; the number at Cincinnati was about 550 , being more than double that at any previous meeting in the West. Over 400 persons joined the Association. Nearly 200 papers were presented ; it is not derogatory to any author to say that these papers were of average interest only, and comprised no startling announcements. The general management was very successful. The chief feature of the meeting was the adoption of the important changes in the constitution which are expected to simplify business in the future. If any complaint can be made, it is of the rather generous disposition on the part of the Sectional Committees towards authors whose productions are of doubtful novelty and uncertain value. There is a tendency also to overrun the allotted time; papers for which twenty-five minutes are asked consume seventy minutes, and those of ten minutes extend to thirty minutes. The remedy of this evil lies with the chairmen of the sections, and it is hoped that they will hereafter exert their powers more frequently. The social features of the meeting were very enjoyable ; the reception at Highland House, and the daily lunches served in the Exhibition building brought together citizens and members in pleasant intercourse.

Prof. Wm. B. Rogers of Boston, the first presiding officer of the Association, was elected an Honorary Fellow, on the unanimous recommendation of both Sections $\mathrm{A}$ and B. Prof. Rogers is the first Honorary Fellow chosen by the Association.

The amendments to the constitution proposed at the Boston meeting were adopted almost unanimously. They provide for the formation of nine sections, as follows :-A, Mathematics and Astronomy ; B, Physics; C, Chemistry; D, Mechanical Science; E, Geology and Geography ; F, Biology; G, Histology and Microscopy; $\mathrm{H}$, Anthropology; I, Economic Science and Statistics.

Each of the above Sections is to have its own chairman, who is also Vice-President of the Society, and its own Secretary. The amended constitution also creates the office of Assistant-General Secretary, makes certain changes in the composition of the Standing Committee, 
and of the nominating committee. These alterations make the organisation more like that of the British Association for the Advancement of Science, and became necessary on account of the recent rapid growth of the Association. The membership has doubled within two years, being now about I 800 .

The recommendation of the Standing Committee to meet in 1882 at Montreal was adopted with acclamation. The invitation from Minneapolis for I883 was referred to the Standing Committee.

The Association elected Dr. J. W. Dawson of Montreal President for the ensuing year. The time of meeting was fixed for the fourth Wednesday in August, 1882, Nearly seventy Fellows were elected by ballot, and the following officers for 1882 , in accordance with the recommendation of the Nominating Committee, were unanimously elected :-

Officers for 1882. Vice-presidents: Section A, Mathematics and Astronomy, Prof. William Harkness, U.S.N.; Section B, Physics, Prof. T. C. Mendenhall of Columbus; Section C, Chemistry, Prof. H. Carrington Bolton, Ph.D., of Hartford, Conn.; Section D, Mechanical Science, Prof. W. P. Trowbridge, Ph.D., of Columbia College, New York; Section E, Geology, Prof. E. T. Cox of San Francisco; Section F, Biology, Capt. W. H. Dall of Washington, D.C. ; Section G, Histology and Microscopy, Prof. A. H. Tuttle of Columbus, Ohio ; Section $\mathrm{H}$, Anthropology, Prof. Daniel Wilson of Toronto; Section I, Economic Science and Statistics, E. B. Elliot of Washington, D.C.

We have already (vol. xxiv. p. 455) referred to the action taken by the Association in reference to science degrees.

The following are some of the principal papers read at the meeting :-

In Section A : Magnetic survey of Missouri, by Prof. F. E. Nipher; on the methods of determining the solar parallax with special reference to the coming transit of Venus, by Prof. William Harkness; on the wave-lengths of the principal lines of the solar spectrum, by Prof. T. C. Mendenhall ; experiments to determine the comparative strength of globes and cylinders of the same diameter and thickness of sides, by Samuel Marsden historic notes on cosmic physiology, by Dr. T. Sterry Hunt; upon the use of the induction balance as a means of determining the location of leaden bullets imbedded in the human body, by Prof. Alex. Graham Bell; upon a new form of electric probe, by the same; on a new method of applying water-power of small head to effect the direct compression of air to any required high pres sure, by Prof. H. T. Eddy; the needle telephone, a new instrament by Dr. Goodman of Louisville, Ky., by Dr. J. Lawrence Smith; an improved sonometer, by W. Le Conte Stevens; on the great outburst in comet $b$, I $88 \mathrm{r}$, observed at the Cincinnati Observatory, by Prof. Ormond Stone; method of determining the value of the solar parallax from meridian observations of Mars, by Prof. J. R. Eastman; numbers of cometary orbits relative to perihelion distance, by Prof. H. A. Newton; numerical elements of the orbits of the seven electrical vortices to whose motions atmospheric storms are principally due, with the processes by which they have been derived, and examples given of the application of the formula by which their positions on the surface of the earth can be computed for any given time, by Thomas Bassnett; a preliminary investigation of the two causes of lateral deviation of spherical projectiles, based on the kinetic theory of gases, by Prof. H. T. Eddy; note on the theory of the flight of elongated projectiles, by Prof. H. T. Eddy; on the mechanical principles involved in the flight of the boomerang, by Prof. H. T. Eddy; the electrophore and electric lighting, by Mr. E. B. Elliott ; nodular concretions in meteoric iron, bearing on the origin of same, by Dr. J. Lawrence Smith ; an anomalous magnetic property of a specimen of iron, by Dr. J. Lawrence Smith; on the errors to which self-registering clinical thermometers are liable, by Dr. Leonard Waldo; a new radiometer, by Dr. H. Carmichael; a new differential thermometer, by Dr. H. Carmichael; note on an experimental determination of the value of $\pi$, by Prof. T. C Mendenhall; remarks upon, and an exhibition of, Japanese magic mirrors, by the same; on standard time, by $E$. $B$.
Elliott; note on a comparison of Newcomb's tables of Uranus and Neptune, with those of the same planets by Leverrier, by D. P. Todd ; universal energy of light, by Pliny Earle Chase electricity, magnetism, gravitation-their phenomena considered as the manifestations of one force, by S. S. Parsons.

In Section B : On the influence of the structure of the nervefibres upon the production and conduction of nerve-force, by H. D. Schmidt; on the action of pilocarpin in changing the colour of the human hair, by Dr. D. W. Prentiss; the unification of geological nomenclature, by Dr. R. Owen; the life-unit in plants, by Prof. B. D. Halsted; recent discoveries, measurements, and temperature observations made in Mammoth Cave, Ky., by Rev. H. C. Hovey ; influence of forests upon streams, by David D. Thompson; note on the segmentation of the vertebrate body, by Charles Sedgwick Minot; phenomena of grow th in plants, by D. P. Penhallow; the recurrence of faunas in the Devonian rocks of New York, by H. S. Williams; a contribution to Croll's theory of secular climatal changes, by W. J. McGee; the evidence from the drift of Ohio in regard to the origin of Lake Erie, by E. W. Claypole; on some relations of birds and insects, by S. A. Forbes ; Niagara River, its cañon, depth, and wear, by Wm. Hosea Ballou; evolution and its place in geology, by Edward S. Edmunds.

In Section C : Is the law of repetition the dynamic law underlying the science of chemistry? by Miss V. K. Bowers; evidences of atomic motion within molecules in liquids, as based upon the speed of chemical action, by Prof. R. B. Warder ; the con titu. tion of the "atom" of science, by Mrs. A. B. Blackwell; the sources of nitrogen in plants, by Prof. W. O. Atwater; notes in experimental chemistry, by Prof. A. B. Prescott ; determination of phosphorus in iron, by Dr. J. Lawrence Smith; the liquefaction of glass in contact with water at $250^{\circ} \mathrm{C}$., by Prof. H. Carmichael ; the chemistry of fish and invertebrates, by Prof. W. $O$. Atwater; notes in experimental chemistry, by Prof. Albert B. Prescott; the quantitative estination of nitrogen, by Prof. W. O. Atwater ; the quantitative estimation of chlorine, by Prof. W. O. Atwater; the nitrogenous constituents of grasses, by Clifford Richardson.

In Section D (Anthropology): Animal myths of the Iroquois, by Mrs. Erminnie A. Smith; antiquity of man in America, by W. de Haas; progress of archæological research, by W. de Haas; the mound builders : an inquiry into their assumed southern origin, by W. de Haas.

In Section E (Microscopy): On a convenient method of expressing micrometrically the relation between English and metric units of length on the same scale, by William A. Rogers and George F. Ballou.

In Section F (Entomology); On the length of life of butterflies, by Prof. W. H. Edwards; on the life duration of the Heterocera (moths), by Prof. J. A. Lintner; how does the bee extend its tonoue? by A. J. Cook; the egg-sase of Hydrophilus triangularis, by Dr. C. V. Riley; on the oviposition of Prodoxus decipiens, by the same; the cocoon of Gyrinus, by the same ; suggestions of co-operation in furthering the study of entumology, by Prof. B. P. Mann.

\section{THE BRITISH ASSOCIATION \\ REPORTS}

Report of the Committee on Tidal Observations in the Enolish Channel and the North Sea, by J. N. Shoolbred.-In the report it was stated that no official reply had been received by the Committee as to having an international datum for observations, or as to maritime governments giving facilities for detailed observations. The Committee urged the desirability of carrying out a series of observations on the Azores. The Portuguese Government had established a station for registering tides, as had also our own Government at Dover. The Committee hoped before long to have a series of observations giving most important results.

Report of the Committee for Underground Temperature, by Prof Everett. - In the report it was stated that the temperatuie varied from one degree for 30 feet to une degree for 100 feet in going down beneath the surface of the earth in different places. During the past year observations have been made in the East Manchester coal field, the Talavgoch lead mine, Flintshire, and at the Radstock collieries, Bath. With regard to the observations in the East Manchester coal-field, these were respectively 